\title{
Somogy megye skorpiófátyolka faunájának katalógusa (Mecoptera)
}

\author{
ÁBRAHÁM LEVENTE
}

ÁBRAHÁM L.: Catalogue of the scorpion fly fauna of Somogy county (Mecoptera)

Abstract: No faunistical data to the scorpion fly fauna of Somogy county have been published yet. However, several undeterminated speciemens can be found in the insect collection of the Natural History Department of Somogy County Museum, Kaposvár.

\section{Bevezetés}

A skorpiófáfyolkák ősi típusú rovarrendet képviselnek, amelyben ma már csupán mintegy félezer leírt recens fajt találunk. Hazánkban a rend három családja fordul elố, az ismert taxonok száma tíz. Mind országosan, mind Somogy megyében nagyon keveset tudunk a fajok pontos elterjedéséról, mivel hazai specialistája még nem volt ennek a kis rovarrendnek, ámbár a legtöbb hazai gyứjteményben megtalálhatók.

A Somogy Megyei Múzeum gyújteménye is számos példányt ốriz hazánkból és a megye több pontjáról, de ezek az anyagok még feldolgozatlanok.

Természetvédelmi szempontból a Bittacidae család fajai a legtöbb európai országban védettek, de hazánkban veszélyeztetettségük ellenére még nem sikerült őket védetté nyilváníttatni.

\section{Somogy megyében előforduló fajok}

\section{Bittacidae}

Bittacus italicus (Müller, 1766)

Panorpidae

Panorpa communis Linnaeus, 1758

Panorpa germanica Linnaeus, 1758

$\overline{\text { ISSN 1587-1908 (Print); ISSN 2062-9990 (Online) }}$ 
1. táblázat: Somogy megyéból ismert Mecoptera fajok családonkénti megoszlása

\begin{tabular}{|l|c|}
\hline Család & Fajszám \\
\hline Bittacidae & 1 \\
\hline Panorpidae & 2 \\
\hline
\end{tabular}

Irodalom

ÁBRAHÁM, L. 2000: Adatok a Villányi-hegység csőrösrovar faunájához (Mecoptera). - Dunántúli Dolgozatok Természettudományi Sorozat 10: 341-346.

\section{Catalogue of the scorpion fly fauna of Somogy county} (Mecoptera)

\section{LEVENTE ÁBRAHÁM}

In Somogy county only three scorpion flies (Bittacus italicus, Panorpa communis, $P$. germanica) are known. The recorded materials preserved in the collection of Natural History Department of Somogy County Museum, Kaposvár have not been determined yet. The number of the species will be increasing in the future.

Author's address:

Dr. Levente ÁBRAHÁM

Natural History Department

Somogy County Museum

H-7400 Kaposvár

Fố utca 10. P.o. Box 70.

HUNGARY 